\title{
The Rutter Children Behaviour Questionnaire for teachers: from psychometrics to norms, estimating caseness
}

\author{
John M. Klein ${ }^{1}-$ University of Trier, Trier, Germany \\ Alda Gonçalves - University of Minho, Braga, Portugal \\ Carlos F. Silva - University of Aveiro, Aveiro, Portugal
}

\begin{abstract}
To establish the psychometric properties of the RCBQ for completion by teachers and to determine behavioural and emotional problems in young children, as they occur in the classroom, we asked 45 elementary school teachers of the north of Portugal to rate classroom behaviour of their pupils based on Rutter Children's Behaviour Questionnaire for teachers. A total of 970 Portuguese mid class children (530 girls and 440 boys) aged between 8 to 11 years $(\mathrm{M}=8.47 ; \mathrm{SD}=.771)$ were evaluated. A two factor structure was found to be suitable, exhibiting an acceptable reliability and test-retest values along a 3 -month period. An average of $16.1 \%$ of the pupils exhibited some behavioural problems, where teachers described anxiety (3.1\%), worry $(5.1 \%)$ and unconcentration $(14.1 \%)$ as the most prevalent symptoms. The findings suggest that the translated scale could serve as a rapid and useful screening instrument in clinical and in research settings.

Keywords: epidemiology; child psychopathology; behavior problems; classroom.
\end{abstract}

Inventário do comportamento de Rutter para professores: da psicometria as normas, estimando

\section{Resumo}

Com o objetivo de estabelecer as propriedades psicométricas do Inventário do Comportamento de Rutter na sua forma completa para professores e, determinar os problemas comportamentais e emocionais em crianças, tal como eles ocorrem na sala de aula, foi pedido a 45 professores do $1^{\circ}$ CEB do Norte de Portugal para classificarem os comportamentos de 970 alunos (530 meninas e 440 meninos), com idades compreendidas entre os 8 e os 11 anos $(M=8,47 ; D P=0,771)$. Foi encontrada uma estrutura fatorial de dois fatores, que exibiu uma fidelidade e valores de teste-reteste aceitáveis ao longo de um período de 3 meses. Verificou-se que 16,1\% dos alunos apresentavam algum problema ao nível do comportamento, e foram descritos pelos professores como os sintomas mais prevalentes: ansiedade $(3,1 \%)$, preocupação $(5,1 \%)$ e dificuldades de concentração $(1,1 \%)$. Os resultados mostram que o instrumento traduzido pode ser útil e simples tanto em contexto clínico como de investigação.

Palavras-Chave: epidemiologia; psicopatologia da infância; problemas de comportamento; sala de aula.

\section{Introduction}

Throughout the last years some data has highlighted problematic rates of emotional and behavioural problems in school-aged children (e.g. Caron \& Rutter, 1991). This increased a world-wide consensus regarding the urge for primary prevention, early detection, and proper management of behavioural and emotional disorders. Usually children's behavioural and emotional symptoms have been divided into two main groups, externalising and internalising symptoms. Externalising refers to deregulation of behaviour and internalising to problems in regulating emotions and mood. This classification has been adopted in many studies as a useful way to systematise the spectrum and prevalence of psychiatric symptoms and disorders, and their antecedents, and thus to promote psychiatric services for children, and to develop preventive measures in the field of child mental health (Costello, Burns, Angold \& Leaf, 1993). Attending to a comprehensive review of the published estimates of the prevalence of these disorders in different countries they vary widely from $3 \%$ to $39 \%$, with a median of $12 \%$ (McGee, Silva \& Williams, 1984; Verhulst, 1995; Verhulst \& van der Ende, 1992a;). Further, psychopathology of a significant degree of severity and associated with impairment of functioning has been identified in 6 $19 \%$ of children and adolescents in studies from different parts of the world (Achenbach \& Howell, 1993; Fombonne, 1994; Klein, Gonçalves, Silva \& Peixoto, 2008; Serrão, Klein \& Gonçalves, 2007; Velez, Johnson \& Cohen, 1989). But if the definition of a disorder includes subjects with a mild level of disturbance, the overall rates increase to $50 \%$.

Research undertaken in Europe and across the Atlantic has clearly revealed that progressively younger children than ever have been perceived as exhibiting behaviour problems in educational settings

\footnotetext{
${ }^{1}$ Endereço para correspondência:

Klinisch Psychologie and Psychotherapie, Fachbereich I - Psychologie, Universität Trier, D - 54286 Trier, Germany

E-mail: jkein@iep.uminho.pt
} 
(Clarizio \& McCoy, 1983; Lawrence \& Steed, 1984; Papatheodorou \& Ramasut, 1993). Consequently, management of such problems appears to become an imperative duty for teachers. Most of the studies on the course of disorders concern the home environment, as they are based on parents' reports and children's self-reports (Ferdinand, Verhulst \& Wiznitzer, 1995; Verhulst \& van der Ende, 1992a; Verhulst \& van der Ende, 1992b). School, however, has an independent impact on children's development (Kasen, Johnson \& Cohen, 1990; Ouston, Mauhgan \& Mortimore, 1980; Rutter, Mauhgan \& Mortimore, 1979). Children's problems at school show a somewhat different spectrum compared with home (Offord, Boyle \& Racine, 1989; Verhulst \& Akkerhuis, 1989), and teachers provide unique information for evaluating the severity of children's psychopathology (Verhulst \& van der Ende, 1997). Behaviours as inattention, calling out, disturbing others and non-compliance are some of the most commonly reported classroom disruptive behaviours, and fall under the definition of "....any behaviour that significantly interferes with the child's own learning, other children's learning or responses, or the teacher's ability to operate effectively" (Merrett \& Wheldall, 1984, p. 87). Comorbidity has been discussed in the child psychiatry literature, especially in the 1990s (Caron \& Rutter, 1991; McConaughy \& Achenbach, 1994; Rutter, 1997). Fairly little research has been conducted on comorbidity in the school environment with teachers acting as informants of children's problems. Although it is important to notice that a diagnose based uniquely on the survey of symptoms, the reports of parents and teachers regarding the complaints of the infants is an unreliable practice. Since 2001, the American Psychological Association and the North-American Academy of Infant and Adolescent Psychiatry, have continuously being alerted for the fact that there is an exaggeration in the diagnoses of behavioural problems in children. Additionally, this specific view increases the medicalization perspective of disruptive behaviours and forgets the social and cultural determinants of those behaviours (Conrad, 2008). Those errors in judging and evaluating behaviours are committed by parents and teachers because the used inventories may be based on non-specific diagnostic criteria, which leads toward a generalization of the behaviours in some diagnostic syndromes, that may not be the most adequate to the needs of the child and leads to a wide variety of interventions (Daw, 2001).

Concerning the use of quick screening and information gaining screening tools adequate for classroom proposal, one scale has been successfully used and accepted by teachers to fulfil this endeavour. Indeed, since his development, the Rutter Children's Behaviour Questionnaire for completion by teachers (RCBQ - Rutter, 1967) has been one of the most wide spreading behavioural assessment tool in classroom environment. The scale has exhibited to have good validity and reliability in measuring the prevalence of childhood disorders in infancy (Boyle \& Jones, 1985). In the course of the years, the scale has been successively analyzed by factor analysis in order to describe the internal structure of the items. Thus, Behar and Stringfield (1974) obtained a three factor solution composed of a "hostile-aggressive", an "anxious-fearful" and a "hyperactive distractible" dimension. Similarly, McGee et al. (1985) studied a sample of New Zealand's children and found three main factors "aggressiveness", "anxiety-fearful" and "hyperactivity", which remain relatively stable during a two year period.

Although, Fowler and Park (1979) found in a study with normal population only a two factor solution, somewhat similar to Behar and Stringfield's (1974) first and last factor. In another study, with subjects of different areas in Mauritius, Venables et al. (1983) found also two factors, namely "aggressiveness-hyperactivity" and "anxious-fearful". Further, this study found also no gender differences and stability for different ethnic groups. These results were similar to the Ekblad (1990) study with a sample of Chinese children from Beijing indicating a two factor structure with "hyperactiveaggressiveness" and "worry-fearfulness" and without any gender differences. Berklund (1999) used latent variable analysis to explore the factor structure of the RCBQ, obtaining a two factor structure labelled as introversive and extroversive.

Regarding the reliability, this scale has been mainly assessed for test-retest and inter-ratter reliability. Thus, Rutter (1967) obtained a .89 correlation value for a test-retest procedure, as Zimmermann-Tansella, Minchetti, Tacconi and Tansella (1980), using the Italian version gathered a slightly lower value of .80 . Moreover the reliability values decrease to .72 and .50 when considered as inter-ratter evaluation (Rutter, 1967; ZimmermannTansella et al., 1980).

The aim of the present study was: a) to determine the psychometric properties of the RCBQ for completion by teachers and, (b) to determine behavioural and emotional problems in young children, as they occur in the classroom, based on teachers report. Given the lack of psychometric properties of the Portuguese RCBQ, the factor 
structure and reliability was determined; normative data and estimation of behavioural and emotional related problems of elementary school children were also calculated.

\section{Method}

\section{Sample}

We asked elementary school teachers of the north of Portugal to rate classroom behaviour of their pupils. Thus, 970 children $(530$ girls and 440 boys) aged between 8 to 11 years (M=8.47; $\mathrm{DP}=.771$ ) were evaluated by their teachers. The forty-five teachers who participated were all females, aged between 35 and 55 years $(M=43.59 ; \mathrm{SD}=7.9)$, with a minimum of 8 years of teaching experience and know each pupil at least for one and a half year period. Regarding to school grades the sample distributes as followed: three-hundred and seventy pupils $(38.14 \%)$ of the $2^{\text {nd }}$ grade, two-hundred and seventy-eight of the $3^{\text {rd }}$ grade $(28.66 \%)$, and threehundred and twenty-two were of $4^{\text {th }}$ grade $(33.20 \%)$. All pupils were out of the mid-class social status and had not been referenced (or being in treatment) for any psychiatric or psychological services.

\section{Instruments}

The Rutter Children's Behaviour Questionnaire (Rutter, 1967) for completion by teachers is a 26item survey designed to evaluate children's behaviour at school. Answers are rated on a scale of 0 to 2, with higher ratings indicating more severe presence of the symptoms. Possible ratings on the scale range from 0 to 52. The Portuguese version of Azevedo, Barreto, Faria and Robalo (1986) was used.

\section{Procedure}

First, the Regional Educational Boards of the North were asked for authorizations and considerations about ethical proceedings. After their agreement, we established contacts with the schools and teachers in order to elaborate a data collection plan that would not interfere with regular teaching activities inside the classroom. The teachers received no training and/or information about the instrument in order to avoid possible biases, although a member of research team was constantly available to discuss and clarify possible doubts. Teachers only rated a maximum of ten pupils in order to avoid possible ratter biases. Teachers assigned a code number to each student in their class, and rated the questionnaire anytime during a specific week, defined by the research team. Once completed the questionnaire, they were placed in an envelope and returned to the school's main office, where they were picked up from the school secretaries by members of the research team. The procedure for the retest was similar; there were two retest evaluations, the first retest was after a 30-days period and the second one after a 3-month period.

The response rate to the questionnaires was very high $(97 \%)$. The number of children screened according to the original sample was 1000 , but 30 questionnaires were incorrectly completed or not returned, thus leaving 970 children for the analysis.

\section{Results}

Table1. Structure matrix of the Portuguese RCBQ;

\begin{tabular}{|c|c|c|}
\hline Item themes & & \\
\hline & 1 & 2 \\
\hline bullying & ,878 & \\
\hline disliked & & ,864 \\
\hline disobedient & ,817 & \\
\hline aggressiveness &, 790 & \\
\hline lying & ,786 & \\
\hline irritable & ,761 & \\
\hline fussy & & ,674 \\
\hline destroying &, 557 & \\
\hline anxious & &, 555, \\
\hline restless & ,490 & \\
\hline painful & & ,355 \\
\hline nail biting & & ,332 \\
\hline squirmy & ,337 & \\
\hline solitary & & ,755 \\
\hline unhappy & &, 708 \\
\hline apathetic & & 663 \\
\hline tearful & & ,655 \\
\hline truant & &, 591 \\
\hline tics & &, 551 \\
\hline stuttering & &, 542 \\
\hline unconcentrated & ,495 & \\
\hline absent & & ,471 \\
\hline worried & & ,387 \\
\hline violent & ,272 & \\
\hline sucking & &, 342 \\
\hline eigenvalues & 6.85 & 5.92 \\
\hline$\%$ of variance & 26.34 & 25.21 \\
\hline excluded item: thievish &,- 041 &,- 089 \\
\hline
\end{tabular}

\section{Factor structure}

An exploratory factor analysis, was performed to verify underlying dimensions of the Portuguese RCBQ. The scree test and eigenvalues greater than one criteria was applied and suggested a nine-factor 
solution which account for $79 \%$ of the total variance. However, the first factor accounted for $26 \%$ of the variance and the second factor for $25 \%$, whereas factors 3 through 7 accounted for additional $28 \%(9 \%, 5 \%, 5 \%, 5 \%$ and $4 \%$ respectively). Further data examination and analysis of the items formulation and theoretical constructs indicated that a two-factor solution $(51 \%$ of total variance explained) may provide the most meaningful interpretation for this sample. Except for the item about thievish activities, which showed a very low factor loading (rang-ing from .041 to .089 in scale 1 or scale 2 respectively), and therefore it was not considered for additional analyses. All other items showed factor loadings ranging from .27 to .87 (cf. Table 1). Herewith the final factor structure for the Portuguese RCBQ were as followed: Factor 1 Extrovert behaviour disorder - comprises 11 items (items: bullying, disobedient, aggressiveness, lying, irritable, destroying, restless, squirmy, unconcentrated and violent), and Factor 2 Introvert behaviour disorder - aggregate 15 items (items: disliked, fussy, anxious, painful, nail biting, solitary, unhappy, apathetic, tearful, truant, tics, stuttering, absent, worried and sucking).

Table 2 - Internal consistency of the RCBQ global score and subscale.

\begin{tabular}{ccc}
\hline $\begin{array}{c}\mathrm{RCBQ} \\
\text { global score }\end{array}$ & $\begin{array}{c}\text { Extrovert behaviour } \\
\text { disorder }\end{array}$ & $\begin{array}{c}\text { Introvert } \\
\text { behaviour } \\
\text { disorder }\end{array}$ \\
\hline$\alpha=.853$ & $\alpha=.785$ & $\alpha=.816$ \\
\hline
\end{tabular}

\section{Reliability analysis}

Once determined a two-factor solution we analysed the internal consistency, item means and item-scale correlation of the RCBQ Global Score and their subscales (extrovert behaviour disorder and introvert behaviour disorder) were calculated. These results, summarized in Table 2, showed quite acceptable internal consistency values, exceeding the level recommended by Nunnally and Bemstein (1994). The item-scale correlations for the remaining items ranged from .32 to .69 .

In addition we determined the stability of RCBQ scores over time (30-day period, three month period). Table 3 presents the correlation coefficients found be tween the first evaluation and each subsequent RCBQ score. All values were considerably high $(\mathrm{p}=.001)$ for both retest moments. The correlation coefficients varied of .39 to .89 , and were all significant for $\mathrm{p}=.001$.
Table 3 - Correlation coefficients for the RCBQ evaluations.

\begin{tabular}{lccc}
\hline N=970 & $\begin{array}{c}\mathrm{RCBQ} \\
\text { Global } \\
\text { Score }\end{array}$ & $\begin{array}{c}\text { extrovert } \\
\text { behaviour } \\
\text { disorder }\end{array}$ & $\begin{array}{c}\text { introvert } \\
\text { behaviour } \\
\text { disorder }\end{array}$ \\
\hline $\begin{array}{l}1^{\text {st }} \text { evaluation }- \\
2^{\text {nd }} \text { evaluation } \\
\text { (after 30 days): }\end{array}$ & $.85^{*}$ & $.77^{*}$ & $.73^{*}$ \\
$1^{\text {st evaluation }-}$ & $.80^{*}$ & $.73^{*}$ & $.70^{*}$ \\
$3^{\text {rd } \text { evaluation }}$ & & & \\
(after 3 \\
months):
\end{tabular}

Table 4 - Percentile ranks for RCBQ global score and subscale scores $(\mathrm{N}=970)$

\begin{tabular}{lcccc}
\hline & & $\begin{array}{c}\text { Total } \\
\text { score }\end{array}$ & $\begin{array}{c}\text { Introvert } \\
\text { behaviour }\end{array}$ & $\begin{array}{c}\text { Extrovert } \\
\text { behaviour }\end{array}$ \\
\hline Mean & & 970 & 970 & 970 \\
Std. deviation & & 5,85 & 3,06 & 1,79 \\
Percentiles & 5 & 0,00 & 0,00 & 0,00 \\
& 10 & 0,00 & 0,00 & 0,00 \\
& 15 & 0,00 & 0,00 & 0,00 \\
& 20 & 0,00 & 0,00 & 0,00 \\
& 25 & 1,00 & 0,00 & 0,00 \\
& 30 & 1,00 & 1,00 & 0,00 \\
& 35 & 2,00 & 1,00 & 0,00 \\
40 & 2,00 & 1,00 & 0,00 \\
45 & 3,00 & 2,00 & 0,75 \\
& 50 & 3,00 & 2,00 & 1,00 \\
55 & 5,00 & 3,00 & 1,00 \\
60 & 5,00 & 3,00 & 1,00 \\
65 & 5,00 & 4,00 & 2,00 \\
70 & 6,00 & 4,00 & 2,00 \\
75 & 7,00 & 4,25 & 2,00 \\
80 & 8,00 & 5,00 & 3,00 \\
85 & 10,00 & 6,75 & 4,00 \\
90 & 11,00 & 7,50 & 5,00 \\
95 & 15,75 & 9,25 & 6,00 \\
\hline
\end{tabular}

\section{RCBQ data}

The Table 4 presents the raw score means and standard deviations for the global score and RCBQ subscales. In order to provide a better understanding of the individual's position in the normative sample we converted the raw subscale scores and global score to percentile ranks. Of note, no statistically significant differences for gender and school grade were found regarding the total and subscales scores. Even so, taking into account each of the symptoms, gender differences were found in three of them: boys had higher scores for bullying $(\mathrm{M}=.24 ; \mathrm{SD}=.53$; $\mathrm{p}=.000)$ than girls $(\mathrm{M}=.09 ; \mathrm{SD}=.34)$ and for 
disobedient behaviour (boys, $\mathrm{M}=.19 ; \mathrm{SD}=.45$; girls, $\mathrm{M}=.08 ; \mathrm{SD}=.30)(\mathrm{p}=.026)$, as girls had scored higher for sucking behaviour $(\mathrm{M}=.19, \mathrm{SD}=.43 ; \mathrm{p}=.019)$ than boys $(\mathrm{M}=.08, \mathrm{SD}=.32)$.

Table 5. Item distribution on the Rutter teacher's scale B, first evaluation ( $\mathrm{n}=970$ )

\begin{tabular}{|c|c|c|c|c|c|c|}
\hline \multirow{3}{*}{ Item } & \multicolumn{6}{|c|}{$N=970$} \\
\hline & \multicolumn{2}{|c|}{ Does not apply } & \multicolumn{2}{|c|}{ Applies somewhat } & \multicolumn{2}{|c|}{ Definitely applies } \\
\hline & $\mathrm{N}$ & $\%$ & $\mathrm{~N}$ & $\%$ & $\mathrm{~N}$ & $\%$ \\
\hline restless & 750 & 77.3 & 186 & 19.2 & 34 & 3.5 \\
\hline truant & 940 & 96.9 & 20 & 3.1 & 10 & 1.1 \\
\hline anxious & 622 & 64.2 & 318 & 32.7 & 30 & 3.1 \\
\hline destroying & 848 & 87.5 & 106 & 11.0 & 16 & 1.6 \\
\hline bullying & 840 & 86.7 & 100 & 10.2 & 30 & 3.1 \\
\hline disliked & 874 & 90.1 & 62 & 6.3 & 34 & 3.6 \\
\hline worried & 556 & 57.3 & 364 & 37.6 & 50 & 5.1 \\
\hline solitary & 768 & 79.2 & 182 & 18.8 & 20 & 2.0 \\
\hline irritable & 830 & 85.5 & 92 & 9.4 & 48 & 5.1 \\
\hline unhappy & 722 & 74.5 & 220 & 22.7 & 28 & 2.7 \\
\hline tics & 844 & 87.1 & 106 & 11.0 & 20 & 1.9 \\
\hline sucking & 856 & 88.2 & 98 & 10.2 & 16 & 1.6 \\
\hline nail biting & 738 & 76.1 & 190 & 19.6 & 42 & 4.3 \\
\hline absent & 920 & 94.9 & 30 & 3.1 & 20 & 2.0 \\
\hline disobedient & 856 & 88.2 & 98 & 10.2 & 16 & 1.6 \\
\hline unconcentrated & 598 & 61.6 & 236 & 24.3 & 136 & 14.1 \\
\hline apathetic & 688 & 71.0 & 220 & 22.7 & 62 & 6.3 \\
\hline fussy & 860 & 88.6 & 88 & 9.0 & 22 & 2.4 \\
\hline lying & 906 & 93.3 & 44 & 4.7 & 20 & 2.0 \\
\hline squirmy & 954 & 98.4 & 12 & 1.2 & 4 & .4 \\
\hline painful & 846 & 87.1 & 110 & 11.4 & 14 & 1.6 \\
\hline tearful & 918 & 94.6 & 38 & 4.0 & 14 & 2.4 \\
\hline stuttering & 810 & 83.5 & 64 & 6.7 & 96 & 9.8 \\
\hline violent & 864 & 89.0 & 88 & 9.1 & 18 & 1.9 \\
\hline aggressiveness & 864 & 89.0 & 62 & 6.3 & 44 & 4.7 \\
\hline
\end{tabular}

Further, no significant differences were found for the global scores, subscales scores or items per se between the first evaluation, the 30-day retest and the 3 -month retest. Thus, the results will be described for caseness regarding the results of the first evaluation period. Considering a cut off score higher than the 80th percentile, a value of nine points at the RCBQ global score, such as considered in previous studies (Azevedo et al., 1986; Rutter, 1967), we noticed that $16.1 \%$ of our sample exhibited some behavioural problems. From out of the behavioural problems, listed along the questionnaire items, the teachers described anxiety $(3.1 \%)$, worry $(5.1 \%)$ and unconcentration $(14.1 \%)$ as those symptoms that were most prevalent and clearly identifiable for them (definitely applies). On the other hand, symptoms like squirmy $(.4 \%)$, truant $(1.1 \%)$ and tics $(1.9 \%)$ were rated as not so often present.

\section{Discussion}

This paper aimed a twofold purpose: (a) to determine the psychometric properties of the RCBQ for completion by teachers and, (b) to determine behavioural and emotional problems in young children, as they occur in the classroom, based on teachers report. Thus, the obtained two-factor solution seemed to be an adequate structure for describing the Portuguese version of this questionnaire. Further this solution is to somewhat similar to the studies of Ekblad (1990), Venables et al. (1983) and Fowler and Park (1979). The division into extrovert and introvert behavioural problems seems to be a suitable and comprehensible matrix for analysing the information covered by this scale. Indeed the obtained structure is similar to those found by Berklund (1999), and therefore supports the assumption of a two factor solution in non clinical samples as the best descriptive structure of the scale 
(e.g. Venables et al., 1983). Although, there was an item that needed to be excluded of the obtained structure, respectively the item concerning thievish activities. Some reasons for this may be: the children's age and the low prevalence of this behaviour during this period; teacher's playing down attitude in front of possible thievish activities inside the classroom, and minimizing the facts or interpreting it as a joke in order to children's age.

Both reliability and test-retest values show that this questionnaire is a suitable tool for teachers at assessing children's behaviour in classroom context. These results are in line with those of previous studies (e.g., Rutter, 1967; Zimmermann-Tansella et al., 1980) and especially they show a great consistency of the teacher's report in terms of the test-retest evaluation values. Thus, this scale showed to be a reliable measure for assessing behavioural and emotional problems among schoolchildren.

In this study, the rate of behaviour disorders in urban Portuguese schoolchildren was $16.1 \%$. This is less than that described for inner London children $(19.1 \%)$ (Rutter, 1973), in Uganda (18\%) (Minde, 1976) and in Lusaka (14.8\%) (Lin \& Ebrahim, 1991), but higher than the frequency observed in Finland $(13.9 \%)$ (Almqvist et al., 1999), in Bangladesh $(13.4 \%)$ (Rabbani \& Hossain, 1999), in Saudi Arabia $(13.4 \%)$ (Abolfotouh, 1997) and in Beijing (8.3\%) (Wang, Shen, Gu, Jia \& Zhang, 1989). Although the high disturbance rates obtained on the teacher questionnaire are similar to what other surveys in similar areas have found (Kolvin et al., 1981; Rutter, 1973), they may reflect a pervasive bias among teachers to overrate the items, perhaps in an attempt to draw attention to problems with children in their classes. However, teachers differ in their attitudes towards disturbed children (Kolvin at al., 1981) and the items come from such relatively distinct domains of interpersonal, affective, and behavioural problems, that the likelihood of a pervasive overrating bias seems low.

Another important aspect to explain this bias may be the pressure that behaviour problems place on teachers giving the disturbance factor that is caused by it during their classroom activities; therefore, it is not surprising that studies examining teacher attitudes have found that they are apprehensive, reluctant and less tolerant of children with behaviour difficulties in their classroom (Forlin, Douglas, \& Hattie, 1996; Harvey, 1992; Idol, 1997; Moeller \& Ishii-Jordan, 1996). Teachers report feeling poorly equipped to deal with behavioural problems, often pointing to their lack of experience and preparation (Martin, Linfoot \& Stephenson, 1999).
Although it is likely that confidence is one of many variables that influence teachers' effectiveness in classroom management, there is a growing body of research indicating that teacher confidence is an important mediator in determining how teachers interact with difficult students and how they manage misbehaviour (Martin et al., 1999; Pajares, 1992).

School health services are making the first steps in Portugal, and educational psychologists are not always present in each school setting. Thus, for children who have an emotional or behavioural disorder, there will be perhaps very little skilled help available. This raises the question of the natural history of such disorders. In the present study, some gender differences were found regarding to abnormal behaviour, although these differences should not be overemphasized before performing a larger study which takes differences in the social and demographic background of the family in terms of social class, family size, crowding index, parents' education, birth order and parental death into account. Other important issues, which also should be extended in future studies, are the possible mediating factors, such as family functioning, parenting capacity, and social and peer relationships. The Rutter scale, which was used for screening, describes general mental health problems and does not focus on specific stress-related problems. Furthermore, we did not use structured psychiatric interviews with the children: their general mental health problems were rated by adult informants (teachers). Further, this scale does not include many questions about somatic symptoms, such as bronchial asthma, headaches or body pain. Nevertheless, the finding of a high rate of mental problems must highlight the importance of training teachers in the areas of child mental health, class management and prevention of child psychiatric disturbances.

Finally, some methodological issues should be taking into account. There are problems in measuring comorbidity in epidemiological research. Behavioural and emotional problems are typically measured by symptom scales and, from a statistical point of view, the deviant category (syndrome) is defined by cut points on the scale. Comorbidity, on the other hand, is not dimensional but by definition entails caseness. In our study, we constructed the deviant categories based on the internalising and externalising scales. Therefore, these categories covary with the pure internalising and externalising syndromes. The selection of cut points on the original scales has a strong influence on the comorbidity rates, which represents a problem for a reliable assessment of comorbidity rates. We defined behavioural and 
emotional deviance by a score higher than the 80th percentile in the frequency distribution of internalising and externalising scales.

\section{Conclusion}

Even if the Portuguese version of the RCBQ revealed to be a valid and reliable tool, for both clinical and non-clinical settings, it is important to notice some key aspects that should be developed in future research. More measures of disruptive behaviours should be used to evaluate children's classroom behaviour. Self-report measures and multiinformants should be taken into account, as well as the need to evaluate the teachers self-efficacy to diagnose and cope with such problems. Additionally, the influence of forms of support, such as a school psychologist or welfare coordinator, should also be taken into account to evaluate teachers confidence in behaviour management. Teachers are active agents in the educational process and therefore, they influence and are influenced by it. Under this umbrella measures should be aware of the objective and subjective perception of the classroom reality.

With the increase of evaluation several aspects can be drawn out and integrated into training of educational agents, in which they will be able to cope and respond with increased efficacy to behavioural problems in the classroom context. Furthermore, they will be able to develop a setting, in which children can reach high achievements, experiences, emotional and social well-being. Finally, the children can use the classroom as a save harbour for developing their personality, abilities and resources.

\section{References}

Abolfotouh, M A. (1997). Behaviour disorders among urban schoolboys in south-western Saudi Arabia. Eastern Mediterranean Health Journal, 3, 274-283.

Achenbach, T. M. \& Howell, C. T. (1993). Are American children's problems getting worse? A 13-year comparison. Journal of the American Academy of Child and Adolescent Psychiatry, 32, 1145-1154.

Almqvist, F., Kumpulainen, K., Ikäheimo, K., Linna, S-L., Hentonnen, I., Huikko, E., TuompoJohansson, E., Aronen, E., Puura, K., Piha, J., Tamminen, T., Räsänen, E. \& Moilanen, I. (1999). Behavioural and emotional symptoms in 8-9 year old children. European Child \& Adolescent Psychiatry, 8(4), 7-16.
Azevedo, M. H. P., Barreto, M. M., Faria, M. M. \& Robalo, M. M. (1986). Questionário Comportamental para ser completado por professors: estudo de fidedignidade. Psiquiatria Clínica, 7(3), 203-207.

Behar, L. \& Stringfield, S. (1974). A Behaviour Rating Scale for the pre-school child. Developmental Psychology, 10(5), 601-610.

Berklund, L. (1999). Latent Variable Analysis of the Rutter Children's Behaviour Questionnaire. Scandinavian Journal of Educational Research, 43(4), 433-442.

Boyle, M. H. \& Jones, S. C. (1985). Selecting measures of emotional and behavioral disorders of childhood for use in general populations. Journal of Child Psychology \& Psychiatry, 26, 137159.

Caron, C. \& Rutter, M. (1991). Comorbidity in child psychopathology: concepts, issues and research strategies. Journal of Child Psychology and Psychiatry, 32, 1063-1080.

Clarizio, H. F. \& McCoy, G. F. (1983). Behaviour Disorders in Children. New York: Harper and Row.

Conrad, Peter (2008). The medicalization of society. Baltimore: The Johns Hopkins University Press.

Costello, E. J., Burns, B. J., Angold, A. \& Leaf, P. J. (1993). How can epidemiology improve mental health services for children and adolescents? Journal of the American Academy of Child and Adolescent Psychiatry, 32, 1106-1113.

Daw, J. (2001). The Ritalin debate. Monitor on Psychology, 32, 64.

Ekblad, S. (1990). The children's behaviour questionnaire for completion by parents and teachers in a Chinese sample. Journal of Child Psychology and Psychiatry, 31, 775-791.

Ferdinand, R. F., Verhulst, F. C., Wiznitzer, M. (1995). Continuity and change of self-reported problem behaviours from adolescence into young adulthood. Journal of the American Academy of Child and Adolescent Psychiatry, 34, 680-690.

Fombonne, E. (1994). The Chartres study: I. prevalence of psychiatric disorders among French school-aged children. British Journal of Psychiatry, 164, 69-79.

Forlin, C., Douglas, G. \& Hattie, J. (1996). Inclusive practices: How accepting are teachers? International. Journal of Disability, Development and Education, 43, 119-133. 
Fowler, P. C. \& Park, R. M. (1979). Factor structure of the pre-school behaviour questionnaire in a normal population. Psychology Report, 45, 599-606.

Harvey, D. (1992). Integration in victoria: teachers' attitudes after six years of a no-choice policy. International Journal of Disability, Development and Education, 39, 33-45.

Idol, L. (1997). Key questions related to building collaborative and inclusive schools. Journal of Learning Disabilities, 30, 384-394.

Kasen, S., Johnson, J. \& Cohen, P. (1990). The impact of school emotional climate on student psychopathology. Journal of Abnormal Child Psychology, 18,165-177.

Klein, J. M., Gonçalves, A., Silva, C. F. \& Peixoto, T. (2008). Problemas de Sono-vigilia em Crianças: um estudo da prevalência. Psico-USF, 13(1), 5158.

Kolvin, I., Garside, R. F., Nicol, A. R., Macmillan, A., Wolstenholme, F. \& Leitch, I. M. (1981). Help starts here: the maladjusted child in the ordinary school. London: Tavistock.

Lawrence, J. \& Steed, D. M. (1984). European voices on disruptive behaviour in schools: definitions, concern and types of behaviour. British Journal of Educational Studies, 32(1), 4-17.

Lin, Y-Q \& Ebrahim, G. J. (1991). Frequency of behaviour disorder and related factors in schoolchildren in Lusaka. Journal of Tropical Paediatrics, 37, 303-309.

Martin, A., Linfoot, K. \& Stephenson, J. (1999). How teachers respond to concerns about misbehaviour in their classroom. Psychology in the Schools, 36, 347358.

McConaughy, S. H. \& Achenbach, T. M. (1994). Comorbidity of empirically based syndromes in matched general population and clinical samples. Journal of Child Psychology and Psychiatry, 35, 11411157.

McGee, R., Silva, P. A. \& Williams, S. (1984). Behavior problems in a population of seven-yearold children: prevalence, stability and types of disorder - A research report. Journal of Child Psychology and Psychiatry, 25, 251-259.

McGee, R., Williams, S., Bradshaw, J., Chapel, J. L., Robins, A. \& Silva, P. A. (1985). The Rutter scale for completion by teachers: factor structure and relationships with cognitive abilities and family adversity for a sample of New Zealand children. Journal of Child Psychology and Psychiatry, 26, 727739.
Merrett, F. \& Wheldall, K. (1984). Classroom behaviour problems which junior school teachers find most troublesome. Educational Studies, 10, 8792.

Minde, K. K. (1976). Psychological problems in Ugandan schoolchildren: a controlled evaluation. Journal of Child Psychology and Psychiatry and Applied Disciplines, 16, 49-59.

Moeller, A. \& Ishii-Jordan, S. (1996). Teacher efficacy: a model for teacher development and inclusion. Journal of Behavioral Education, 6, 293310.

Nunnally, J. C., \& Bemstein, I. H. (1994). Psychometric theory (3rd ed.). New York: McGraw-Hill.

Offord, D. R., Boyle, M. H. \& Racine, Y. (1989). Ontario child health study: correlates of disorder. Journal of the American Academy of Child and Adolescent Psychiatry, 28, 856-860.

Ouston, J., Maughan, B. \& Mortimore, P. (1980). School influences. Em M. Rutter (Org.). Scientific Foundations of Developmental Psychiatry (pp.67-76). London: Medical Books Limited.

Pajares, F. (1992). Teachers' beliefs and educational research: cleaning up a messy construct. Review of Educational Research, 62, 307-332.

Papatheodorou, T. \& Ramasut, A. (1993). Teachers' attitudes towards children's behaviour problems. International Journal of Early Years Education, 1(3), 35-47.

Rabbani, M. G. \& Hossain, M. M. (1999). Behaviour Disorders in urban primary schoolchildren in Dhaka, Bangladesh. Journal of Public Health, 133, 233-236.

Rutter, M. (1967). A children's behaviour questionnaire for completion by teachers: preliminary findings. Journal of Child Psychology and Psychiatry, 8, 1-11.

Rutter, M. (1973). Why are London children so disturbed? Proceedings of the Royal Society of Medicine, 66, 1221-1225.

Rutter, M. (1997). Comorbidity: concepts, claims and choices. Criminal Behaviour and Mental Health, 7, 265-285.

Rutter, M., Maughan, B. \& Mortimore, P. (1979). Fifteen Thousand Hours. London: Open Books. Serrão, F., Klein, J. M. \& Gonçalves, A. (2007). Qualidade do Sono e Depressão: que relações sintomáticas em crianças de idade escolar. PsicoUSF, 12(2), 257-268. 
Velez, C. N., Johnson, J. \& Cohen, P. (1989). A longitudinal analyses of selected risk factors for childhood psychopathology. Journal of the American Academy of Child and Adolescent Psychiatry, 28, 861-864.

Venables, P. H., Fletcher, R. P., Dalais, J. C., Mitchell, D. A., Schulsinger, F. \& Mednick, S. A. (1983). Factor structure of the Rutter Children's Behaviour Questionnaire in a primary-school population in a developing country. Journal of Child Psychology and Psychiatry and Applied Disciplines, 24, 213-222.

Verhulst, F. C. (1995). The epidemiology of child and adolescent psychopathology: strengths and limitations. Em F. C. Verhulst \& H. M. Koot (Orgs.). The epidemiology of child and adolescent psychopathology (pp. 1-21). New York: Oxford University Press.

Verhulst, F. C. \& Akkerhuis, G. W. (1989). Agreement between parents' and teachers' ratings of behavioural/emotional problems of children aged 4-12. Journal of Child Psychology and Psychiatry, 30, 123-136.

Verhulst, F. C. \& van der Ende, J. (1992a). Six year developmental course of internalising and externalising problem behaviours. Journal of the
American Academy of Child and Adolescent Psychiatry, 31, 924-931.

Verhulst, J. \& van der Ende, J. (1992b). Six year stability of parent-reported problem behaviour in an epidemiological sample. Journal of Abnormal Child Psychology, 20, 595-611.

Verhulst, F. C. \& van der Ende, J. (1997) Factors associated with child mental health service use in the community. Journal of the American Academy of Child and Adolescent Psychiatry, 36, 901-909.

Wang, Y. F., Shen, Y. C., Gu, B. M., Jia, M. X. \& Zhang, A. L. (1989). An epidemiological study of behaviour problems in schoolchildren in urban areas of Beijing. Journal of Child Psychology and Psychiatry and Applied Disciplines, 30, 907-912.

Zimmermann-Tansella, C., Minchetti, T., Tacconi, A. \& Tansella, M. (1980). The children's Behaviour Questionnaire for completion by teachers in an Italian sample: preliminary results. Journal of Child Psychology and Psychiatry, 19, 167-173.

Recebido em novembro de 2008 Reformulado em abril de 2009 Aprovado em maio de 2009

Sobre os autores:

John M. Klein é doutor em Psicologia Clínica e atualmente é professor na Universidade de Trier (Alemanha). Tem publicado e apresentado vários trabalhos nas seguintes áreas de interesse: Psicopatologia, Processos e Resultados Terapêuticos, Avaliação Psicológica e Neurociências.

Alda Gonçalves é licenciada em Psicologia pela Universidade do Minho (Portugal), onde atualmente está completando o Mestrado em Psicologia Clínica. Nos últimos anos, tem-se dedicado a estudar as perturbações do comportamento alimentar e as perturbações de sono.

Carlos Fernandes da Silva: é doutor em Psicologia Clínica e professor catedrático na Universidade de Aveiro (Portugal). Tem publicado e apresentado inúmeros trabalhos nas seguintes áreas: Cronociências, Psicofisiologia, Neurociências, Psicologia Clínica e Psicopatologia. 